\title{
Peran Promosi Kesehatan Terhadap Perbaikan Pengetahuan, Sikap, Dan Perilaku Membuang Sampah Pada Siswa Sekolah Menengah Atas
}

\author{
Cucu Herawati ${ }^{1}$, Iin Kristanti ${ }^{2}$, Mely Selviana ${ }^{3}$, Tri Novita ${ }^{4}$ \\ STIKes Cirebon \\ 1 e-mail: cucuherawati502@gmail.com \\ 2e-mail: inkris76@gmail.com \\ ${ }^{3}$ e-mail: selviana.melly@yahoo.com \\ ${ }^{4}$ e-mail: trinovita365@gmail.com
}

\begin{abstract}
ABSTRAK
Permasalahan sampah semakin rumit dengan meningkatnya taraf hidup masyarakat, yang tidak disertai dengan keselarasan pengetahuan dan juga partisipasi masyarakat yang kurang untuk memelihara kebersihan. Penelitian ini bertujuan untuk mengetahui peran promosi kesehatan terhadap perbaikan peningkatan pengetahuan, sikap dan perilaku membuang sampah pada siswa SMA. Penelitian ini menggunakan pendekatan Quasi Eksperimen dengan rancangan One Group Pretest-Posttest. Sampel sebanyak 61 responden. Data dianalisis dengan menggunakan uji T test. Penelitian menunjukkan adanya perbedaan pengetahuan $(\mathrm{p}=0,000)$, sikap $(\mathrm{p}=0,009)$ dan perilaku $(0,000)$ siswa dalam membuang sampah pada tempatnya sebelum dan sesudah pemberian intervensi promosi kesehatan. Intervensi promosi kesehatan berpengaruh terhadap perbaikan pengetahuan, sikap, dan perilaku siswa dalam membuang sampah pada tempatnya. Perlu adanya kerjasama pihak sekolah dengan Puskesmas untuk melakukan promosi kesehatan secara kontinu.
\end{abstract}

Kata Kunci: Promosi Kesehatan; Pengetahuan; Sikap; Perilaku.

\begin{abstract}
The problem of waste is complicated by the increasing standard of living of the people, which is not accompanied by a harmony of knowledge and also a lack of community participation to maintain cleanliness. This study aims to determine the role of health promotion in improving the improvement of knowledge, attitudes, and behavior in disposing of trash in high school students. This study uses a Quasi Experiment approach with the One Group Pretest-Posttest design. The sample was 61 respondents. Data were analyzed using the T-test. Research shows differences in knowledge $(p=0,000)$, attitudes $(p=0.009)$, and behavior $(0,000)$ of students in disposing of trash in their place before and after giving health promotion interventions. Health promotion interventions affect the improvement of students' knowledge, attitudes, and behavior in disposing of trash in their place - the collaboration between the school and Puskesmas to carry out continuous health promotion.
\end{abstract}

Keywords: Health Promotion; Knowledge; Attitude; Behavior 


\section{PENDAHULUAN}

Sebagai salah satu Negara berkembang dengan jumlah penduduk lebih dari 200 juta jiwa, masalah kesehatan lingkungan di Indonesia menjadi sangat kompleks. Hampir setiap tempat di Indonesia, system pembuangan sampah dilakukan secara dumping tanpa ada pengelolaan lebih lanjut. Sistem pembuangan semacam itu, selain memerlukan lahan yang cukup luas juga menyebabkan pencemaran pada udara, tanah dan air, selain lahannya juga dapat menjadi tempat berkembangbiaknya agent dan vector penyakit menular (Chandra, 2007).

Kenyataannya, pola penanganan sampah tersebut belum mampu menyelesaikan permasalahan yang muncul. Hal ini dikarenakan tidak seimbangnya jumlah timbulan sampah dengan kapasitas pengelolaannya, karena berdasarkan target dan sasaran yang ditetapkan dalam MDGS (Millenium Development Goals) bahwa cakupan pelayanan persampahan harus mencapai $70 \%$ penduduk pada tahun 2015, komitmen tersebut juga diperkuat dalam Peraturan Menteri Pekerjaan Umum Nomor 21/PRT/M/2006 tentang Kebijakan dan Strategi Nasional Pengembangan Sistem Pengelolaan Persampahan (KNSP-SPP) (Nasution, 2017). Sekolah menempati kedudukan strategis pendidikan dalam upaya promosi kesehatan, dikarenakan sebagaian besar anak-anak usia 519 tahun terpajan dengan lembaga pendidikan dalam jangka waktu yang lama (taman kanak-kanak sampai sekolah lanjutan atas) dan sekolah mendukung pertumbuhan dan perkembangan alamiah seorang anak (Kementerian Kesehatan RI, 2010). PHBS tatanan institusi pendidikan adalah sekumpulan perilaku yang dilakukan oleh siswa/peserta didik, guru dan masyarakat yang ada dilingkungan sekolah atas dasar hasil pembelajaran, sehingga secara mandiri mampu mencegah penyakit, meningkatkan kesehatannya, serta berperan aktif dalam mewujudkan lingkungan sehat (A Raharjo, 2014).

Permasalahan sampah tidak hanya terjadi di dalam rumah tangga, tetapi juga di sekolah. Sebagai sebuah komunitas dengan anggota yang besar, sampai saat ini kebijakan pengolahan sampah mandiri belum menyentuh lembaga sekolah (Rudarti, 2010). Salah satu parameter sekolah yang baik adalah berwawasan lingkungan. Di dalam parameter tersebut tidak bisa dilepaskan dari pola pengelolaan sampahnya (Andry, 2009).

Hasil Statistik Riskesdas yang diperoleh pada tahun 2013 yang berperilaku merusak lingkungan seperti membuang sampah pada selokan, sungai dan parit sebanyak 10,4\%, dan dibuang sembarangan sejumlah 9,7\% (Kementerian Kesehatan RI Badan Penelitian dan Pengembangan, 2018). Sampah bila ditimbun sembarangan sebagai sarang lalat atau tikus. Seperti kita ketahui lalat adalah vector berbagai penyakit demikian juga dengan tikus, yang dapat menyebarkan penyakit pest (Juli Soemirat Slamet, 2007). Jumlah Penderita Diare yang ditangani di Jawa Barat tahun 2016 sebanyak 1.032.284 orang, atau 80,6\% dari target sasaran 
(Diskesjabarprov, 2014) Berdasarkan data promosi kesehatan UPTD Puskesmas Suranenggala tahun 2017 perilaku hidup bersih dan sehat (PHBS) sekolah membuang sampah pada tempatnya 61,3\% (Promosi kesehatan, 2018). Ada perbedaan yang signifikan antara pengetahuan, sikap dan praktik sebelum dan sesudah dilakuakan intervensi promosi kesehatan pada siswa (Fatimah, 2012).

Pengelolaan sampah di SMA N 1 Suranenggala Kabupaten Cirebon berdasarkan observasi, siswa saat istirahat setelah makan, ada beberapa siswa yang membuang sampah bukan pada tempatnya. Tempat sampah yang digunkan jenis tempat sampah terbuka sehingga memungkinkan sampah tersebut berserakan terbawa angin. Ruang kelas yang berdekatan dengan TPA kurang nyaman karena asap pembakaran dan bau kurang sedap yang ditimbulkan oleh sampah. Seringkali siswa tidak masuk sekolah karena sakit penyebabnya adalah demam dan diare. Tujuan penelitian ini untuk mengetahui peran promosi kesehatan terhadap perbaikan pengetahuan, sikap dan perilaku membuang sampah pada siswa SMA N 1 Suranenggala Kabupaten Cirebon.

\section{BAHAN DAN METODE}

\section{Domain perilaku sehat}

Seorang ahli psikologi Benyamin Bloom (1908) membagi perilaku manusia itu ke dalam 3 domain, ranah atau kawasan yakni: kognitif (cognitive), afektif (affective), psikomotor (psychomotor). Dalam perkembangannya, teori Bloom ini dimodifikasi untuk pengukuran hasil pendidikan kesehatan, yakni: terbagi menjadi pengetahuan (knowledge), sikap (attitude), dan praktik (practice). Dengan penjelasan 3 domain perilaku sebagai berikut (Notoatmodjo, 2013), (Notoatmodjo, 2007):

\section{Pengetahuan (Knowledge)}

Pengetahuan adalah hasil penginderaan manusia atau hasil tahu seseorang terhadap objek melalui indera yang dimilikinya dengan sendirinya, pada waktu penginderaan sampai menghasilkan pengetahuan tersebut sangat dipengaruhi oleh intensitas perhatian dan persepsi terhadap objek. Pengetahuan atau kognitif merupakan domain yang sangat penting dalam membentuk tindakan seseorang (overtbehavior). Pengetahuan terhadap objek mempunyai intensitas atau tingkat yang berbeda, yaitu tahu (knowledge), memahami (comprehension), aplikasi (application), analisis (analysis), sintesis (synthesis) dan evaluasi (evaluation). (Notoatmodjo, 2013) (Notoatmodjo, 2007).

Apabila penerimaan perilaku baru atau adopsi perilaku melalui proses yang disadari oleh pengetahuan, kesadaran, dan sikap yang positif, maka perilaku tersebut akan bersifat langgeng (longlasting). Sebaliknya apabila perilaku tidak didasari oleh pengetahuan dan kesadaran 
maka tidak akan berlangsung lama. Seseorang sebelum mengadopsi perilaku, ia harus tahu terlebih dahulu apa arti atau manfaat perilaku tersebut bagi dirinya atau keluarganya (Notoatmodjo, 2007). Pengetahuan merupakan hasil dari tahu dan ini terjadi setelah orang melakukan penginderaan terhadap suatu objek tertentu, selanjutnya dikatakan pengetahuan merupakan domain sangat penting untuk terbentuknya tindakan seseorang. ${ }^{\text {(noto) }}$ Pengetahuan tentang kesehatan mungkin diperlukan sebelum dilakukan praktik kesehatan, tetapi praktik kesehatan yang diinginkan mungkin tidak terjadi kecuali jika seseorang menerima petunjuk yang cukup kuat, yang memotivasinya untuk bertindak atas dasar pengetahuan yang dimiliki (Mubarak, 2007).

\section{Sikap (Attitude)}

Sikap merupakan reaksi/respon yang masih tertutup dari seseorang terhadap suatu stimulus atau objek, yang sudah melibatkan faktor pendapat dan emosi yang bersangkutan, disimpulkan bahwa sikap merupakan produk dari proses sosialisasi di mana seseorang bereaksi sesuai dengan rangsangan yang diterimanya, sehingga sikap yang akan timbul sangat dipengaruhi oleh pengetahuan sesorang (Notoatmodjo, 2013). Newcomb salah seorang ahli psikologis sosial, menyatakan bahwa sikap itu merupakan kesiapan atau kesediaan untuk bertindak, dan bukan merupakan pelaksanaan motif tertentu. Sikap belum merupakan suatu tindakan atau aktivitas, akan tetapi merupakan predisposisi tindakan suatu perilaku. Sikap itu masih merupakan reaksi tertutup, bukan merupakan reaksi atau tingkah laku yang terbuka (Notoatmodjo, 2007).

Setelah seseorang mengetahui stimulus atau objek, proses selanjutnya akan menilai atau bersikap terhadap stimulus atau objek kesehatan tersebut. Oleh karena itu indikator untuk sikap kesehatan sejalan dengan pengetahuan kesehatan. Sikap mempunyai tingkatan berdasarkan intensitasnya, yaitu: menerima (receiving), menangani (responding), menghargai (valuing), bertanggung jawab (responsible), sehingga sikap adalah kecenderungan untuk bertindak (tendtobehave) (Notoatmodjo, 2013).

3. Tindakan (practice)

Suatu sikap belum otomatis terwujud dalam suatu tindakan (overtbehaviour), untuk mewujudkan sikap menjadi suatu perbuatan nyata diperlukan faktor pendukung atau suatu kondisi yang memungkinkan, antara lain adalah adanya fasilitas yang mendukung. Setelah seseorang mengetahui stimulus atau objek kesehatan, kemudian mengadakan penilaian atau pendapat terhadap apa yang diketahui, proses selanjutnya diharapkan ia akan melaksanakan atau mempraktikan apa yang diketahui atau disikapinya (Notoatmodjo, 2007). Suatu sikap belum otomatis terwujud dalam suatu tindakan (overtbehaviour) dan untuk mewujudkan sikap 
menjadi suatu perbuatan nyata diperlukan faktor pendukung atau suatu kondisi yang memungkinkan, antara lain dengan faktor pendorong dan faktor penguat (Notoatmodjo, 2003). Makin banyak segi positif dari komponen pengetahuan maka makin penting komponen itu, sehingga akan makin positif sikap yang terbentuk, sebaliknya makin banyak segi negatifnya, maka makin negatif sikap yang terbentuk (Vidiyani, 2005).

\section{Promosi Kesehatan}

Promosi kesehatan menurut Green dan Kreuter yaitu kombinasi dari upaya pendidikan dan lingkungan agar tercipta dindakan dan suasana untuk hidup sehat. Promosi Kesehatan menurut WHO, yang menyatakan promosi kesehatan yaitu proses memampukan masyarakat untuk mengontrol dan meningkatkan kesehatannya. Promosi Kesehatan disini lebih kepada proses social dan politik yang komprehensif, tidak hanya upaya langsung untuk meningkatkan skill dan kemampuan individu, tetapi juga upaya langsung untuk memperbaiki kondisi lingkungan fisik, sosial, ekonomi, serta mengurangi dampak buruk dari lingkungan tersebut (Zaeri, 2001). Ada 8 indikator PHBS di institusi pendidikan diantaranya membuang sampah pada tempatnya. Di institusi pendidikan (kampus, sekolah, pesantren, siminari, padepokan dan lain-lain), sasaran primer harus mempraktikkan perilaku yang dapat menciptakan institusi pendidikan ber-PHBS. Siswa dan masyarakat sekolah wajib membuang sampah pada tempat sampah yang telah disediakan. Siswa diharapkan tahu dalam memilih jenis sampah seperti sampah organic maupun sampah non organik. Sampah yang berserakan dilingkungan sekolah dapat menimbulkalkan penyakit dan tidak indah.

Penelitian ini menggunakan pendekatan Quasi Eksperimen dengan rancangan One Group Pretest-Posttest (Notoatmodjo, 2005). Teknik pengambilan sampel menggunakan teknik Proportional Random Sampling dengan sampel sebanyak 61 responden. Metode pengumpulan data dengan wawancara dan observasi. Data dianalisis dengan menggunakan uji T test, pada tingkat kemaknaan $10 \%(0,1)$. Promosi kesehatan merupakan intervensi dengan memberikan informasi kepada siswa mengenai pengetahuan, sikap dan praktik membuang sampah pada tempatnya, dengan tujuan untuk memperbaiki pengetahuan, sikap, dan praktik siswa dalam membuang sampah pada tempatnya. 


\section{HASIL DAN PEMBAHASAN}

Tabel 1. Perbedaan Pengetahuan, Sikap, dan Praktik Membuang Sampah Pada Tempatnya

(Pre dan Post) pada Siswa SMA N.

\begin{tabular}{lccc}
\hline \multicolumn{1}{c}{ Variabel } & $\begin{array}{c}\text { Pretest } \\
\text { Mean } \pm \text { SD }\end{array}$ & $\begin{array}{c}\text { Posttest } \\
\text { Mean } \pm \text { SD }\end{array}$ & Nilai p \\
\hline Pengetahuan & $6.10 \pm 0.300$ & $7.74 \pm 0.854$ & 0.000 \\
Sikap & $30.98 \pm 2.533$ & $31.95 \pm 2.883$ & 0.000 \\
Praktik & $5.93 \pm .512$ & $6.30 \pm 0.407$ & 0.009 \\
\hline
\end{tabular}

Sumber: Data Primer, 2019

Berdasarkan tabel 2. hasil penelitian menunjukkan rata-rata skor pengetahuan mengalami peningkatan dari sebelum intervensi sebesar 6.10 menjadi 7.74 sesudah intervensi, rata-rata skor sikap sebelum intervensi sebesar 30.98 menjadi 31.95 setelah intervensi, dan rata-rata skor praktik membuang sampah pada tempatnya dari 5.93 menjadi 6.30 setelah intervensi promosi kesehatan pada siswa SMA N.

Hasil uji $\mathrm{T}$ berpasangan pengetahuan diperoleh nilai $\mathrm{p}=0.000$ maka disimpulkan ada perbedaan pengetahuan siswa tentang membuang sampah pada tempatnya sebelum dan sesudah pemberian intervensi promosi kesehatan, sikap diperoleh nilai $\mathrm{p}=0.000$ maka disimpulkan ada perbedaan sikap siswa terhadap membuang sampah pada tempatnya sebelum dan sesudah pemberian intervensi promosi kesehatan, dan praktik diperoleh nilai $\mathrm{p}=0.009$ maka disimpulkan ada perbedaan praktik dalam membuang sampah pada tempatnya sebelum dan sesudah pemberian intervensi promosi kesehatan pada siswa SMA N.

\section{Pengaruh promosi kesehatan terhadap pengetahuan membuang sampah}

Berdasarkan hasil penelitian ini menunjukkan adanya peningkatan rata-rata skor pengetahuan tentang membuang sampah pada tempatnya sebelum dan sesudah intervensi promosi kesehatan dan ada perbedaan pengetahuan siswa tentang membuang sampah pada tempatnya sebelum dan sesudah pemberian intervensi promosi kesehatan, hasil penelitian sejalan dengan hasil penelitian sebelumnya yang menyatakan bahwa perbaikan pengetahuan informasi kesehatan diperoleh dari berbagai media, adanya perbedaan pengetahuan antara sebelum diberi pendidikan kesehatan dengan sesudah diberikan pendidikan kesehatan (Banum, 2016). Mahasiswa mempunyai pengetahuan yang baik, dimana pengetahuan mahasiswa tersebut diperoleh dari berbagai media. Oleh karena itu adanya peningkatan pengetahuan dibuktikan dengan adanya perbedaan pengetahuan antara sebelum dengan sesudah diberikan pendidikan kesehatan (Nurhadyana, 2012). 
Pengetahuan merupakan hasil pengindraan manusia, atau hasil tahu seseorang terhadap objek melalui indra yang dimilikinya, pada waktu pengindraan menghasilkan pengetahuan tersebut sangat dipengaruhi oleh intensitas perhatian dan persepsi terhadap objek. Sebagian besar pengetahuan seseorang diperoleh melalui indra pendengaran (telinga) dan indra penglihatan (mata) (Notoatmodjo, 2014). Teori Green menjelaskan bahwa suatu perilaku ditetukan oleh faktor predisposisi (predisposing factors), faktor ini digunakan untuk mempermudah seseorang untuk berperilaku, misalnya pengetahuan, sikap, keyakinan, adat istiadat, tradisi, dan sebagainya. Untuk dapat menerapkan PHBS di lingkungan sekolah, maka perlu diberikannya pengetahuan tentang perilaku tersebut. Dengan pemberian pengetauan ini, diharpkan dapat membentuk sikap siswa tentang kehidupan yang sehat, sehingga hal tersebut dpat diterapkan menjadi suatu kebiasaan untuk berperilaku bersih dan sehat disekolah (Lina, 2016).

Promosi Kesehatan di sekolah adalah suatu bentuk upaya dalam meningkatkan kemampuan peserta didik, guru dan masyarakat lingkungan sekolah agar mandiri dalam mencegah penyakit, memelihara kesehatan, menciptakan dan memelihara lingkungan sehat, terciptanya kebijakan sekolah sehat serta berperan aktif dalam meningkatkan kesehatan masyarakat sekitarnya (Depkes RI, 2008). Dengan mendengar dan menyimak seseorang akan semakin banyak mendapat informasi yang mampu menambah pengetahuan, dalam penelitian ini bertambahnya pengetahuan siswa tentang membuang sampah pada tempatnya. Hal ini menunjukkan bahwa dengan pendekatan intervensi promosi kesehatan terbukti efektif dapat meningkatkan pengetahuan tentang pembuangan sampah pada tempatnya di sekolah.

Pengetahuan merupakan domain sangat penting untuk terbentuknya tindakan seseorang. begitu juga informasi media massa yang diperoleh baik dari pendidikan formal maupun non formal dapat memberikan pengaruh jangka pendek sehingga menghasilkan perubahan atau peningkatan pengetahuan (Notoatmodjo, 2013). Dengan demikian upaya meningkatkan pengetahuan tentang tentang membuang sampah pada tempatnya perlu mendapat perhatian utama agar siswa lebih berperan aktif dalam melakukannya. Responden yang berpengetahuan baik akan berpeluang lebih besar mempunyai perilaku baik dalam membuang sampah pada tempatnya dibanding dengan responden yang berpengetahuan kurang baik.

\section{Pengaruh promosi kesehatan terhadap sikap membuang sampah}

Adanya peningkatan rata-rata skor sikap terhadap membuang sampah pada tempatnya sebelum dan sesudah intervensi promosi kesehatan dan adanya perbedaan sikap siswa terhadap membuang sampah pada tempatnya sebelum dan sesudah pemberian intervensi promosi kesehatan, hasil penelitian ini sejalan dengan hasil penelitian sebelumnya yang menyatakan bahwa adanya peningkatan sikap siswa setelah menerima pendidikan kesehatan melalui metode ceramah 
(Pratama, 2013). Menurut teori Kohlberg dalam ahmad sigit (2014) pola pikir anak usia sekolah berubah dari egosentrisme ke pola pikir logis. Anak usia sekolah mampu menilai suatu tindakan berdasarkan niat dibandingkan akibat yang dihasilkannya. Hasil uji statistik pada nilai rata-rata sikap tentang PHBS menunjukkan bahwa adanya perbedaan yang bermakna antara sebelum dan sesudah diberikan intervensi promosi kesehatan (Kurnia, 2014).

Sikap merupakan respon tertutup seseorang terhadap stimulus atau objek tertentu, yang melibatkan faktor pendapat dan emosi. Newcomb, menyatakan bahwa sikap merupakan kesiapan atau kesediaan untuk bertindak, dan bukan merupakan pelaksanaan motif tertentu. Dalam kata lain fungsi sikap belum merupakan tindakan (reaksi terbuka), atau aktifitas, akan tetapi merupakan predisposisi perilaku (tindakan), atau reaksi tertutup (Fatimah, 2012). Setelah seseorang mengetahui stimulus atau objek, proses selanjutnya akan menilai atau bersikap terhadap stimulus atau objek kesehatan tersebut (Notoatmodjo, 2007). Sikap juga mempunyai tingkatan. Tingkatan sikap tersebut terdiri dari menerima (Receiving), merespon (Responding), menghargai (Valuting), bertanggung jawab (Responsible). Menerima diartikanbahwa seseorang mau dan memperhatikan rangsangan yang diberikan kepadanya. Merespon yaitu memberikan tanggapan balik terhadap sesuatu yang ditanyakan, mengerjakan sesuatu dan menyelesaikan tugas yang diberikan. Menghargai yaitu mengajak orang lain untuk mengerjakan/ mendiskusikan suatu masalah. Bertanggung jawab merupakan segala sesuatu yang telah dipilihnya dengan segala resiko yang akan dihadapinya. Tanggung jawab merupakan sikap yang paling tinggi Sikap merupakan produk dari proses sosialisasi di mana seseorang bereaksi sesuai dengan rangsangan yang diterimanya,sehingga sikap yang akan timbul sangat dipengaruhi oleh pengetahuan sesorang (Notoatmodjo, 2010). Sikap dipengaruhi oleh tingkat pengetahuan yang dimiliki, pengetahuan yang baik akan menimbulkan sikap yang baik pula. Pengetahuan yang meningkat akan mempengaruhi terhadap sikap siswa terhadap membuang sampah pada tempatnya pada penelitian ini.

\section{Pengaruh promosi kesehatan terhadap praktik membuang sampah}

Adanya peningkatan rata-rata skor praktik dalam membuang sampah pada tempatnya sebelum dan sesudah intervensi promosi kesehatan dan adanya perbedaan praktik siswa dalam membuang sampah pada tempatnya sebelum dan sesudah pemberian intervensi promosi kesehatan, hasil penelitian ini sejalan dengan hasil penelitian sebelumnya yang menyatakan bahwa tindakan menyapu lantai dan membersihkan ruang kelas dapat meningkatkan sikap dan perilaku siswa dalam hidup bersih dan sehat (Nurhadyana, 2012). Sehingga untuk terwujudnya sebuah sikap menjadi tindakan yang nyata diperlukan fasilitas pendukung, antara lain fasilitas persampahan. Tidak tersediannya fasilitas yang memadai dalam melakukan PHBS membuang sampah pada 
tempatnya seperti tempat sampah, tong sampah berpenutup, dan tempat pembuangan sampah sementara (TPSS) menjadi sebab/alasan siswa tidak melakukan penerapan membuang sampah pada tempatnya (AS Raharjo, 2014). Ada perbedaan yang bermakna antara pengetahuan, sikap dan praktek Perilaku Hidup Bersih dan Sehat sebelum dan sesudah intervensi promosi kesehatan pada siswa SD (Kurnia, 2014). Ada perbedaan yang bermakna antara pengetahuan, sikap dan praktek Perilaku Hidup Bersih dan Sehat sebelum dan sesudah intervensi promosi kesehatan pada siswa SD (Kurnia, 2014).

Pembinaan PHBS di sekolah pada dasarnya terdiri dari 3 proses, yaitu pemberdayaan, bina suasana, dan advokasi. Pemberdayaan dapat dilaksanakan dalam berbagai cara, seperti pemberian proses belajar dan mengajar, penyelenggaraan klinik konsultasi kesehatan yang dikelola oleh sekolah dan bekerjasama dengan petugas kesehatan. Bina suasana dapat dilakukan oleh semua masyarakat sekolah seperti pemuka masyarakat, pengurus organisasi anak didik, pengurus pramuka dan sebagainya. Sehingga mereka dapat menjadi panutan dalam pelaksanaan PHBS dilingkungan sekolah. Bina suasana juga dapat dilaksanakan dengan memenfaatkan media yang ada, seperti pembuatan majalah dinding (madding), poster serta penyelenggaraan seminar mengenai kesehatan dan perilaku sehat. Sedangkan advokasi dilakukan oleh fasilitator yang berasal dari kabupaten, kota atau provinsi terhadap pihak sekolah, sehingga pihak sekolah berperan aktif dalam menunjang kegiatan pembinaan PHBS di sekolah (Kementerian Kesehatan RI, 2011).

Promosi kesehatan merupakan segala bentuk kombinasi antara pendidikan kesehatan dan intervensi yang dirancang untuk memudahkan perubahan perilaku dan lingkungan yang kondusif bagi kesehatan. Sehingga dapat dikatakan bahwa promosi kesehatan merupakan upaya untuk meningkatkan kesehatan secara menyeluruh bukan hanya perubahan perilaku tetapi juga perubahan lingkungan (Notoatmodjo, 2014). Perilaku merupakan suatu aktivitas dari manusia itu sendiri, perilaku yang ada pada individu tidak timbul dengan sendirinya, tetapi akibat dari adanya rangsangan dari individu tersebut (Julismin \& Hidayat, 2013). Ketika pengetahuan seseorang meningkat maka akan mempengaruhi perilaku seseorang menjadi baik dalam penelitian ini perilaku siswa tidak lagi membuang sampah sembarangan. Perubahan perilaku memerlukan waktu yang lama berbeda dengan prinsip belajar dimana belajar merupakan proses evolusi, untuk merubah perilaku juga memerlukan pemikiran dan pertimbangan orang lain (Kurnia, 2014). Setelah seseorang mengetahui stimulus atau objek kesehatan, kemudian mengadakan penilaian atau pendapat terhadap apa yang diketahui, proses selanjutnya diharapkan ia akan melaksanakan atau mempraktikan apa yang diketahui atau disikapinya (Kurnia, 2014).

Kondisi ini menunjukkan bahwa dari pengetahuan yang semakin baik dapat mempengaruhi sikap menjadi lebih baik. Sikap yang baik ini kemudian diimplementasikan dalam perilaku 
responden dalam berperilaku hidup bersih dan sehat secara baik. Budioro mengatakan bahwa perilaku adalah respon tindakan atau perbuatan suatu organisme yang dapat diamati dan bahkan dipelajari yang dibedakan dalam bentuk pasif dan aktif, bentuk pasif yaitu. respon yang terjadi dalam diri manusia dan tidak secara langsung terlihat oleh orang lain berupa pengetahuan, sikap dan persepsi. Perilaku merupakan diterminan kesehatan yang menjadi sasaran dari promosi atau pendidikan kesehatan. Dengan kata lain promosi atau pendidikan kesehatan bertujuan untuk mengubah perilaku (behavior change) (Nurhadyana, 2012).

Pemberdayaan dalam promosi kesehatan adalah hal yang sangat penting, dikarenakan Pemberdayaan ini merupakan proses agar masyarakat sekolah dapat berperan dalam pengambilan dan penetapan tindakan yang berhubungan dengan kualitas kesehatannya. Pemberdayaan merupakan tindakan pemberian informasi pada kelompok sasaran secara terus menerus, memperhatikan perkembangan sasaran, serta membantu mengubah dari tidak tahu menjadi tahu (Aspek Knowladge), dari tahu menjadi mau (aspek attitude), dan dari mau menjadi mampu untuk melaksankan dan mempraktekkan perilaku yang telah diberikan atau diperkenalkan (aspek practice) (Lina, 2016).

\section{KESIMPULAN DAN SARAN}

Intervensi promosi kesehatan berpengaruh terhadap perbaikan peningkatan pengetahuan, sikap, dan perilaku siswa dalam membuang sampah pada tempatnya. Adanya kerjasama pihak sekolah dengan Puskesmas untuk melakukan promosi kesehatan secara kontinu, menyediakan sarana berupa tempat sampah organik dan non organik, serta membuat peraturan tegas sehingga dapat memberikan sanksi kepda siswa yang membuang sampah sembarangan.

\section{UCAPAN TERIMA KASIH}

Terima kasih kepada seluruh pihak SMA 1 Suranenggala Kabupaten Cirebon yang telah terlibat dalam pelaksanaan penelitian Peran Promosi Kesehatan Terhadap Perbaikan Pengetahuan, Sikap, dan Perilaku Membuang Sampah Pada Siswa Sekolah Menengah Atas, semoga pelaksanaan penelitian pengabdian ini dapat bermanfaat lebih pada masyarakat luas.

\section{DAFTAR PUSATAKA}

Andry. (2009). Gambaran Perilaku Siswa Tentang Pengelolaan Sampah Di Sma Negeri 1 Tamalatea Kab. Jeneponto.

Banum, T. S. (2016). Hubungan Antara Pengetahuan Phbs Dengan Pola Hidup Sehat the Correlation Between Phbs Knowledge and Healthy Lifestyle. Jurnal Pendidikan Guru 
Sekolah Dasar, 14. Retrieved from

http://journal.student.uny.ac.id/ojs/index.php/pgsd/article/download/1951/1680

Chandra, B. (2007). Pengantar Kesehatan Lingkungan. Jakarta: Buku Kedokteran EGC.

Depkes RI. (2008). Promosi Kesehatan di Sekolah. Jakarta: Pusat Promosi Kesehatan.

Diskesjabarprov. (2014). Resume Tabel Profil Kesehatan di Provinsi Jawa Barat.

Fatimah, S. (2012). Pengaruh Intervensi Promosi Kesehatan Terhadap Pengetahuan, Sikap, dan

Praktek Perilaku Hidup Bersih dan Sehat Siswa Kelas 4 dan 5 SDN Kembaran Kecamatan

Loano Kabupaten Purworejo Propinsi Jawa Tengah Tahun 2012. Universitas Indonesia.

Juli Soemirat Slamet. (2007). Kesehatan Lingkungan. Gajah Mada University Press.

Julismin, \& Hidayat, N. (2013). Gambaran Pelayanan dan Perilaku Kesehatan Di Indonesia, 5, 12.

Kementerian Kesehatan RI. (2010). Pemberdayaan Masyarakat Dan Promosi Kesehatan Untuk Hidup Sehat.

Kementerian Kesehatan RI. (2011). Pedoman Pembinaan perilaku hidup bersih dan sehat (PHBS).

Kementerian Kesehatan RI Badan Penelitian dan Pengembangan. (2018). Hasil Utama Riset Kesehatan Dasar. Jakarta. Retrieved from

http://www.depkes.go.id/resources/download/general/Hasil Riskesdas 2013.pdf

Kurnia, A. (2014). Pengaruh Intervensi Promosi Kesehatan Terhadap Pengetahuan, Sikap Dan

Prkatek Perilaku Hidup Bersih Dan Sehat Pada Siswa Kelas 4 Dan 5 Sdn Siluman Iv Kota

Tasikmlaya 2014. Jurnal Kesehatan Bakti Tunas Husada, 12(1). Retrieved from https://ejurnal.stikes-bth.ac.id/index.php/P3M_JKBTH/article/view/73

Lina, H. (2016). Perilaku Hidup Bersih dan Sehat (PHBS) Siswa di SDN 42 Korong Gadang

Kecamatan Kuanji Padang. Jurnal Promkes, 4.

Mubarak. (2007). Promosi kesehatan. Graha Ilmu.

Nasution, A. (2017). Gambaran Perilaku siswa dalam membuang sampah di Madrasah Ibtidaiyah Ibnu 'Aqil Kota Bogor. Jurnal Kesehatan Masyarakat, 5.

Notoatmodjo, S. (2003). Pendidikan Dan Perilaku Kesehatan. Jakarta: Rineka Cipta.

Notoatmodjo, S. (2005). Metodologi Penelitian Kesehatan (3rd ed.). Rineka Cipta.

Notoatmodjo, S. (2007). Promosi kesehatan dan ilmu perilaku. Rineka Cipta.

Notoatmodjo, S. (2010). Pemberdayaan Masyarakat dan Promosi Kesehatan untuk Hidup Sehat. Jakarta: Rineka Cipta.

Notoatmodjo, S. (2013). Pendidikan dan Perilaku Kesehatan. Jakarta: Rineka Cipta.

Notoatmodjo, S. (2014). Ilmu Perilaku Kesehatan. Jakarta: Rineka Cipta. 
Nurhadyana, I. (2012). Faktor-Faktor Yang Berhubungan Dengan Perilaku Membuang Sampah Pada Siswa Sekolah Dasar Negeri (Sdn) Di Kecamatan Bantar Gebang, Tahun 2012. Skripsi Universitas Indonesia.

Pratama, R. K. O. (2013). Pengaruh Pendidikan Kesehatan Terhadap Pengetahuan, Sikap dan Perilaku Tantang Kebiasaan Berperilaku Hidup Bersih dan Sehat Siswa SDN 1 Mandong. Publikasi Universitas Muhammadiyah Surakarta, 1-13. Retrieved from http://eprints.ums.ac.id/27163/13/NASKAH_PUBLIKASI.pdf

Promosi kesehatan. (2018). Profil Puskesmas Suranenggala Kabupaten Cirebon.

Raharjo, A. (2014). Hubungan Antara Pengetahuan, Sikap, D Ketersediaan Fasilitas Di Sekolah Dalam Penerapan PHBS Membuang Sampah Pada Tempatnya. Journal Unnes Public Helath.

Raharjo, A. (2014). Hubungan antara pengetahuan, sikap, dan ketersediaan fasilitas di sekolah dalam penerapan PHBS membuang sampah pada tempatnya. Journal Unnes of Public Helath.

Rudarti. (2010). Pengelolaan Sampah yang Ramah Lingkungan.

Vidiyani. (2005). Hubungan kondisi lingkungan, kontainer, dan perilaku masyarakat dengan keberadaan Jentik nyamuk Aedes aegypti di Daerah endemis DBD Surabaya. Jurnal Kesehatan Lingkungan, 1(2).

Zaeri, 14. (2001). Faktor-faktor yang berhubungan dengan perilaku masyarakat dalam pencegahan penyakit demam berdarah dengue di Kecamatan Kedaton Kota Bandar Lampung. Jurnal Epidemiologi Indonesia, 2(1), 9. 